\title{
Effect of Slider Disc Workouts on Motion Compatibility Components and Skill Performance Level on Ground Movements
}

"Dr/ Ashraf Haidar Abou El Fotouh

Introduction and research problem

In recent years, fitness professionals have become increasingly interested in the use of core stability exercises in athletic training programs, due to the tremendous impact of the benefits of these exercises on sports performance,

Which results in tremendous power to provide maximum performance to the lower and upper end and exercises that have recently become Commonly used by athletes drills using sliding disc are practiced by beginners and high level.

Essam Abdel-Khalek (2003) states that the specific means and devices play an important role within the client training, which helps to manage the goal of training clearly and help the trainer in the economy in time and effort, and increase motivation and enthusiasm among the players $(7: 12)$

According to Muhammad Shehata (2002), the term means refers to the tools and methods by which a player can provide sensory experiences and training positions (physical, motor, skill) to acquire a motor or skill assignment to help facilitate performance $(8: 34)$

Mohammed Osman (2003) points out that the training programs have taken a form, structure and organization that includes with the new development in the devices and means used during the training process,

Which have become a necessity of physical, skill and psychological rehabilitation of the players, it has been proven by experience that their use leads to high levels of sports (10: 153) (16: 21.)

Jensen Schultz (2007) adds that the method of training to develop physical traits is

"Lecturer, Department of Gymnastics, Exercise and Sports Shows, Faculty of Physical Education, Arish University. 
preferable to the type of muscular work, as well as the prevalence of movements performed on devices and auxiliary devices have a positive effect at the skill level. (84:20)

\section{Mohamed Abdelsalam} (2003) points out that the assistive devices have an effective role. They provide the player from the beginning with an almost kinetic imagination about the technical performance with no boredom. Necessary for performance (11:20)

Mukhtar Salem (2001) points out that there are now a huge number of innovations and diverse inventions that serve the different mathematical fields due to the real reasons for the development and ease of the training process through easy access to information and recording and analysis.

The importance of sports technology can be easily realized through a comprehensive and rapid look at the achievements of sports, Olympic and global, thanks to the tremendous technological advances that have solved many problems and obstacles to provide ideal solutions to improve the level of sports and contribute effectively to the cross-border of human Highscores (12: 11.)

Mylrea (2007) believes that this system is specially designed to transform movements into smooth exercise lines of movement as it helps to achieve the optimal goal of movement easily and continuously using a lot of exercises that vary by objective of movement and adds a soft touch to difficult movements Other programs and tools are difficult and sometimes costly, which makes sliding exercises important (23.)

Sliding discs are a simple idea of plates in the form of plates made of plastic or nylon depending on the type of floor and the tool is placed under the feet or hands of the players where the movements are performed in different mobility groups that allow practitioners to simulate the process of ice skating.

Zaire scott (2005) states that the discs are available in two types of plastic or fiber reinforced discs that can be used on smooth or hard floors. Flexible discs are made of nylon, which can be used on 
rugs or carpets, giving the possibility to use indoors. Easy as it is lightweight and easy to use (24.)

Mylrea (2007) notes that Gliding is a complete fitness program that is characterized by continuity in performance without feeling bored or tired, with practitioners feeling happy and cheerful during the performance, and regular ice exercise leads to improved fitness It also adds that the ice exercises are considered aerobic activities,

The aim of which is to acquire the individual aerobic ability and that the exercise of these exercises, which includes exercises to develop strength, flexibility, compatibility, agility and endurance that make the heart beat For her to the highest rate, which helps to raise the efficiency of physiological and physical efficiency (24)

These exercises are a new method for a contemporary fitness program that is practiced in a group form characterized by interesting and fun. General Health Care (25)

Gliding disc exercises are one of the modern trends that aim to use a training method to improve athletic performance in all aspects and through it can develop the physical abilities of the game to contribute to the development of physical performance and have the greatest impact in raising the level of players and the importance of these exercises is a slip involved One or more group of muscles with the aim of lengthening the main muscles in the body $(21: 14$.)

Artistic gymnastics is considered one of the basic sports.It is the core of the sports activity in that it deals with the physical composition of the child as a whole by dealing with the physiological, anatomical and psychological principles in the highest form. Therefore, we raise the physical and skill performance, mental, psychological, emotional and other educational aspects (3: 39)

Ground movements constitute the cornerstone of the gymnastics education. Ground movements contain a large number of artistic groups which are similar to the artistic groups found on other gymnastics machines. 
Therefore, they are considered the basis of gymnastics. They are all closely linked (2:13)

Ashraf Mohamed

Bassim (2000) states that the element of compatibility is a component of fitness that is related to skill performance. Most sports physiologists unanimously divide physical fitness into "health-related components" such as endurance, strength, flexibility, and physical composition. Skill performance, such as speed, ability, agility, compatibility, balance and reaction time, plays an important and essential role in learning, mastering and acquiring motor skills. (4: 2)

Both Massaad and Mahmoud Mahrous Kandil (2005) and Sam Adel (1999), citing Barrow, agree that compatibility is an important fitness component that is directly related to skill performance and learning to master motor skills to get to the mechanical stage.

The more complex the complex motion, the greater the need for compatibility. (17: 128) (18: 3)

Abul Ela Abdel Fattah (1997) states that kinetic compatibility is associated with many other physical attributes such as speed, agility, balance and accuracy. The compatibility of speed is shown in the requirements of kinetic performance in terms of time.

And its parts with the accuracy required during the surrounding vacuum, and therefore the compatibility in the simplest sense means proper motor performance speed and accuracy and agility required with the economy of effort and lack of errors. (1: 205)

Jihan Abdel Moneim (1999) suggests that the components of motor compatibility can be developed through various exercises and gradual in difficulty, as motor compatibility exercises cannot be developed and mastered properly only after repeated training and continuous so that the nervous system to send the nerve signals between the palm and excitement

The development of components of motor compatibility is done by training the player with individual or even exercises using or without tools or 
devices. This is called PAL. Quality Deribat. (5:16)

Through the work of the researcher in the teaching and training of artistic gymnastics, he found that there is a weakness in the level of the components of motor compatibility among students of the Faculty of Physical Education,

Al-Arish University, the second division in gymnastics skills. The researcher drills Gliding disk to see how it affects the development of components of motor compatibility, which can well affect the level of skill performance on the ground movements in artistic gymnastics.

\section{Research Goal}

The aim of this research is to identify the impact of slipping disc exercises on the components of motor compatibility and skill level performance on the ground movement's device

\section{Research hypotheses}

- There are statistically significant differences between the averages of pre and post measurements in the level of components of motor compatibility and the level of skill performance on the ground movements of the second year students experimental research group.

- There are statistically significant differences between the averages of pre and post measurements in the level of components of motor compatibility and the level of skill performance on the ground movements of the second year students of the control group.

- There are statistically significant differences between the two mean measurements in the experimental and control groups in the level of the components of the motor compatibility and the skill performance level on the ground movements of the second year students of the experimental research group

\section{Research plan and procedures \\ Research Methodology:}

The researcher used the experimental method with two pre and post measurements for two groups, one experimental and one control.

\section{Society and Sample Research:}

The research community included (32) students of the second year of the Faculty of Physical Education, Al-Arish University. To conduct research surveys. 


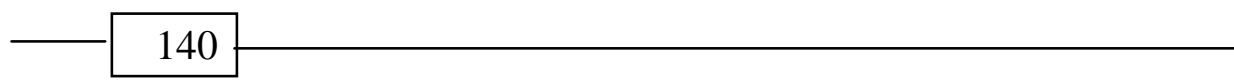

Table (1)

Homogeneity of the total research sample $\mathrm{N}=32$

\begin{tabular}{|c|c|c|c|c|c|c|c|}
\hline Field & $\mathbf{S}$ & Variables & $\begin{array}{c}\text { Measuring } \\
\text { unit }\end{array}$ & Ave & SMA & $\begin{array}{l}\text { Standard } \\
\text { deviation }\end{array}$ & $\begin{array}{c}\text { Torsion } \\
\text { coefficient }\end{array}$ \\
\hline \multirow{4}{*}{ 吾 $\frac{\mathscr{d}}{0}$} & 1 & Height & $\mathrm{Cm}$ & 168.15 & 168.00 & 3.17 & 0.32 \\
\hline & $r$ & Weight & $\mathrm{Kg}$ & 71.66 & 71.60 & 1.22 & 0.002 \\
\hline & $r$ & Age & Year & 19.22 & 19.21 & 0.54 & 0.025 \\
\hline & $\varepsilon$ & Training age & Year & 9.30 & 9.25 & 0.62 & 0.054 \\
\hline \multirow{6}{*}{ 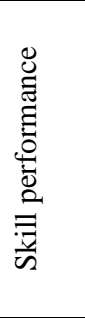 } & 1 & Slow back somersault & Degree & 1.25 & 1.20 & 0.25 & 0.60 \\
\hline & $r$ & $\begin{array}{l}\text { Running from the } \\
\text { wheel position }\end{array}$ & Degree & 1.38 & 1.35 & 0.21 & 0.42 \\
\hline & $r$ & $\begin{array}{l}\text { Stand up on your hands } \\
\text { and get off the chest }\end{array}$ & Degree & 1.51 & 1.50 & 0.036 & 0.83 \\
\hline & $\varepsilon$ & Slow forward somersault & Degree & 1.52 & 1.50 & 0.15 & 0.4 \\
\hline & 0 & $\begin{array}{l}\text { Standing hands } \\
\text { rolling forward }\end{array}$ & Degree & 1.62 & 1.60 & 0.041 & 1.46 \\
\hline & 7 & Total degree & Degree & 7.28 & 7.15 & 0.14 & 2.78 \\
\hline \multirow{6}{*}{ 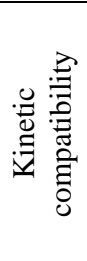 } & 1 & Flexibility & $\mathrm{Cm}$ & 9.66 & 9.61 & 0.41 & 0.32 \\
\hline & $r$ & Power characteristic of speed & $\mathrm{Cm}$ & 1.62 & 1.60 & 0.15 & 0.26 \\
\hline & r & $\begin{array}{l}\text { Ability to make } \\
\text { appropriate effort }\end{array}$ & Degree & 38.44 & 38.40 & 0.17 & 0.21 \\
\hline & $\varepsilon$ & Agility & Freq. & 2.84 & 2.80 & 0.21 & 0.87 \\
\hline & 0 & Motor speed & $\mathrm{S}$ & 9.82 & 9.80 & 0.22 & 0.89 \\
\hline & 7 & Estimate the situation & $S$ & 15.52 & 15.50 & 0.81 & 0.14 \\
\hline
\end{tabular}

It is clear from Table (1) that all values of the torsion coefficients of the total group were between $(+3)$ for the variables of length, weight, age, training age, skill performance and motor compatibility components under consideration for the total group, which confirms the homogeneity of the research sample in those variables.

Means of data collection:

Devices and tools used:

-Medical balance. - Two high jump bars.

-Restameter. - Medical balls $3 \mathrm{~km}$.

-Tape measure. - Sling.

-Colored adhesive tapes.

Ground movement's device.

-Stop Watch. - Whistle.
-Mattresses.-Sony Digital Camera.

Executive steps of the search experience:

\section{Program Objective:}

The program discussion aims at:

under

-Upgrading some components of motor compatibility and skill performance on the ground movements device

Executive steps of the research:

\section{Program content}

The program included (12) week (2) units per week. The researcher took into consideration the graduation in the medium training loads. The training repetitions included one (3: 5) iterations for the sliding disc exercises. 
View and discuss results:

Table (2)

Indication of the differences between the mean of the pre and post measurements of the experimental group in the components of kinetic compatibility and skill performance on the ground movements device $\mathrm{N}=\mathbf{1 2}$

\begin{tabular}{|c|c|c|c|c|c|c|c|c|c|}
\hline \multirow[t]{2}{*}{$\mathbf{S}$} & \multirow[t]{2}{*}{ Variables } & \multirow{2}{*}{$\begin{array}{c}\text { measuring } \\
\text { unit }\end{array}$} & \multicolumn{2}{|c|}{$\begin{array}{c}\text { Pre } \\
\text { measurement }\end{array}$} & \multicolumn{2}{|c|}{$\begin{array}{c}\text { Post } \\
\text { measurement }\end{array}$} & \multirow{2}{*}{$\begin{array}{c}\text { Rate of } \\
\text { improvement }\end{array}$} & \multirow{2}{*}{$\begin{array}{c}T \\
\text { valve }\end{array}$} & \multirow{2}{*}{$\begin{array}{c}\text { Statistical } \\
\text { significance }\end{array}$} \\
\hline & & & $\mathbf{E}$ & M & $\mathbf{E}$ & M & & & \\
\hline$\overline{1}$ & Precision & Degree & $\overline{77.89}$ & $\overline{0.87}$ & $\overline{9.12}$ & $\overline{0.21}$ & $15.58 \%$ & 3.98 & Indicated \\
\hline r & $\begin{array}{l}\text { Power } \\
\text { characteristic } \\
\text { of speed }\end{array}$ & $\mathrm{Cm}$ & 1.61 & 0.24 & 1.83 & 0.25 & $13.66 \%$ & 3.47 & Indicated \\
\hline$r$ & $\begin{array}{l}\text { Ability to } \\
\text { make } \\
\text { appropriate } \\
\text { effort }\end{array}$ & Degree & 38.41 & 0.06 & 43.70 & 0.21 & $13.77 \%$ & 3.41 & Indicated \\
\hline$\varepsilon$ & Agility & Freq. & 2.81 & 0.21 & 3.28 & 0.58 & $16.72 \%$ & 3.66 & Indicated \\
\hline 0 & Motor speed & S & 9.80 & 0.15 & 8.66 & 0.21 & $13.16 \%$ & 3.59 & Indicated \\
\hline 1 & $\begin{array}{l}\text { Estimate the } \\
\text { situation }\end{array}$ & $\mathrm{S}$ & 15.80 & 0.25 & 14.20 & 0.63 & $32.39 \%$ & 3.54 & Indicated \\
\hline 1 & $\begin{array}{l}\text { Slow back } \\
\text { somersault }\end{array}$ & Degree & 1.23 & 0.032 & 2.43 & 0.32 & $97.56 \%$ & 3.54 & Indicated \\
\hline r & $\begin{array}{l}\text { Running } \\
\text { from the } \\
\text { wheel } \\
\text { position }\end{array}$ & Degree & 1.35 & 0.025 & 2.50 & 0.11 & $85.18 \%$ & 3.26 & Indicated \\
\hline$r$ & $\begin{array}{l}\text { Stand up on } \\
\text { your hands } \\
\text { and get off } \\
\text { the chest }\end{array}$ & Degree & 1.48 & 0.017 & 2.20 & 0.17 & $48.64 \%$ & 3.14 & Indicated \\
\hline$\varepsilon$ & $\begin{array}{l}\begin{array}{l}\text { Slow front } \\
\text { somersault }\end{array} \\
\end{array}$ & Degree & 1.51 & 0.032 & 2.60 & 0.021 & $72.18 \%$ & 3.87 & Indicated \\
\hline 0 & $\begin{array}{l}\text { Handstand } \\
\text { rolling } \\
\text { forward }\end{array}$ & Degree & 1.60 & 0.021 & 2.50 & 0.58 & $56.25 \%$ & 3.69 & Indicated \\
\hline 7 & Total degree & Degree & 7.17 & 0.14 & 12.23 & 0.11 & $70.57 \%$ & 3.45 & Indicated \\
\hline
\end{tabular}

The value of $(\mathrm{T})$ to denote the parties at the level of $0.05=1.753$

As shown in Table (2), there are statistically significant differences between the median of the pre and post measurements of the post measurement. experimental group in the variables of motor compatibility and skill performance and in favor of the 
Table (3)

Indication of differences between the mean of the pre and post measurements of the control group in the components of motor compatibility and skill performance on the ground movements device $\mathbf{N}=12$

\begin{tabular}{|c|c|c|c|c|c|c|c|c|c|}
\hline \multirow[t]{2}{*}{$\mathbf{S}$} & \multirow[t]{2}{*}{ Variables } & \multirow{2}{*}{$\begin{array}{c}\text { measuring } \\
\text { unit }\end{array}$} & \multicolumn{2}{|c|}{$\begin{array}{c}\text { Pre } \\
\text { measurement }\end{array}$} & \multicolumn{2}{|c|}{$\begin{array}{c}\text { Post } \\
\text { measurement }\end{array}$} & \multirow{2}{*}{$\begin{array}{c}\text { Rate of } \\
\text { improvement }\end{array}$} & \multirow{2}{*}{$\begin{array}{c}\text { T } \\
\text { valve }\end{array}$} & \multirow{2}{*}{$\begin{array}{c}\text { Statistical } \\
\text { significance }\end{array}$} \\
\hline & & & $\mathrm{M}$ & $E$ & $\mathrm{M}$ & $E$ & & & \\
\hline$\overline{1}$ & Precision & $\overline{\text { Degree }}$ & 7.88 & 0.51 & 7.98 & 0.25 & $2.41 \%$ & 2.11 & Indicated \\
\hline r & $\begin{array}{l}\begin{array}{l}\text { Power } \\
\text { characteristic of } \\
\text { speed }\end{array} \\
\text { spen }\end{array}$ & $\mathrm{Cm}$ & 1.62 & 0.22 & 1.71 & 0.22 & $5.55 \%$ & 2.66 & Indicated \\
\hline$r$ & $\begin{array}{l}\text { Ability to make } \\
\text { appropriate } \\
\text { effort }\end{array}$ & Degree & 38.42 & 0.15 & 39.80 & 0.11 & $5.43 \%$ & 2.14 & Indicated \\
\hline$\varepsilon$ & Agility & Freq. & 2.83 & 0.17 & 2.80 & 0.15 & $1.07 \%$ & 2.54 & Indicated \\
\hline 0 & Motor speed & $\mathrm{S}$ & 9.81 & 0.32 & 8.79 & 0.14 & $4.20 \%$ & 2.12 & Indicated \\
\hline 7 & $\begin{array}{l}\text { Estimate } \\
\text { the situation }\end{array}$ & S & 15.19 & 0.31 & 14.90 & 0.21 & $15.14 \%$ & 2.36 & Indicated \\
\hline 1 & $\begin{array}{l}\text { Slow back } \\
\text { somersault }\end{array}$ & Degree & 1.25 & 0.021 & 1.55 & 0.027 & $24.00 \%$ & 2.63 & Indicated \\
\hline r & $\begin{array}{l}\text { Running from } \\
\text { the wheel } \\
\text { position }\end{array}$ & Degree & 1.38 & 0.052 & 1.94 & 0.021 & $40.57 \%$ & 2.14 & Indicated \\
\hline$r$ & $\begin{array}{l}\text { Stand up on } \\
\text { your hands } \\
\text { and get off } \\
\text { the chest }\end{array}$ & Degree & 1.51 & 0.032 & 1.87 & 0.11 & $23.57 \%$ & 2.54 & Indicated \\
\hline$\varepsilon$ & $\begin{array}{l}\text { Slow front } \\
\text { somersault }\end{array}$ & Degree & 1.50 & 0.014 & 1.88 & 0.14 & $25.33 \%$ & 2.69 & Indicated \\
\hline 0 & $\begin{array}{l}\text { Handstand } \\
\text { rolling forward }\end{array}$ & Degree & 1.61 & 0.017 & 1.91 & 0.011 & $18.63 \%$ & 2.87 & Indicated \\
\hline 7 & Total degree & Degree & 7.25 & 0.021 & 9.15 & 0.0032 & $26.20 \%$ & 2.41 & Indicated \\
\hline
\end{tabular}

The value of $(\mathrm{T})$ to denote the parties at the level of $0.05=1.753$

As shown in Table (3), there are statistically significant differences between the median of the pre and post measurements of the control

\section{Table (4)}

Significance of differences between the two mean measurements of the experimental and control groups in the components of motor compatibility and skill performance on the ground movement's apparatus $\mathrm{N}=\mathbf{2 4}$

\begin{tabular}{c|l|c|c|c|c|c|c|c}
\hline \multirow{2}{*}{$S$} & \multirow{2}{*}{ Variables } & \multirow{2}{*}{$\begin{array}{c}\text { measuring } \\
\text { unit }\end{array}$} & \multicolumn{2}{|c|}{$\begin{array}{c}\text { Experimental } \\
\text { group }\end{array}$} & \multirow{2}{*}{ Control group } & \multirow{2}{*}{$\begin{array}{c}\text { T } \\
\text { valve }\end{array}$} & \multirow{2}{*}{$\begin{array}{c}\text { Statistical } \\
\text { significance }\end{array}$} \\
\cline { 4 - 8 } & & & $\mathrm{E}$ & $\mathrm{M}$ & $\mathrm{E}$ & $\mathrm{M}$ & \\
\hline $\mathbf{r}$ & Precision & Degree & 9.12 & 0.21 & 7.98 & 0.25 & 3.55 & Indicated \\
\hline$r$ & Power characteristic of speed & $\mathrm{Cm}$ & 1.83 & 0.25 & 1.71 & 0.22 & 3.12 & Indicated \\
\hline$r$ & $\begin{array}{l}\text { Ability to make } \\
\text { appropriate effort }\end{array}$ & Degree & 43.70 & 0.21 & 39.80 & 0.11 & 3.98 & Indicated \\
\hline \hline
\end{tabular}

Assiut Journal For Sport Science Arts 
Follow Table (4)

Significance of differences between the two mean measurements of the experimental and control groups in the components of motor compatibility and skill performance on the ground movement's apparatus $\mathrm{N}=\mathbf{2 4}$

\begin{tabular}{|c|c|c|c|c|c|c|c|c|}
\hline \multirow[t]{2}{*}{ S } & \multirow[t]{2}{*}{ Variables } & \multirow{2}{*}{$\begin{array}{c}\text { measuring } \\
\text { unit }\end{array}$} & \multicolumn{2}{|c|}{$\begin{array}{c}\text { Experimental } \\
\text { group }\end{array}$} & \multicolumn{2}{|c|}{ Control group } & \multirow{2}{*}{$\begin{array}{c}\text { T } \\
\text { valve }\end{array}$} & \multirow{2}{*}{$\begin{array}{c}\text { Statistical } \\
\text { significance }\end{array}$} \\
\hline & & & $E$ & $\mathrm{M}$ & $\mathrm{E}$ & $\mathrm{M}$ & & \\
\hline$\varepsilon$ & Agility & Freq. & 3.28 & 0.58 & 2.80 & 0.15 & 3.47 & Indicated \\
\hline 0 & Motor speed & $\mathrm{S}$ & 8.66 & 0.21 & 8.79 & 0.14 & 3.55 & Indicated \\
\hline 7 & Estimate the situation & $\mathrm{S}$ & 14.20 & 0.63 & 14.90 & 0.21 & 3,65 & Indicated \\
\hline 1 & Slow back somersault & Degree & 2.43 & 0.32 & 1.55 & 0.027 & 3.69 & Indicated \\
\hline r & $\begin{array}{l}\text { Running from the wheel } \\
\text { position }\end{array}$ & Degree & 2.50 & 0.11 & 1.94 & 0.021 & 3.41 & Indicated \\
\hline r & $\begin{array}{l}\text { Stand up on your hands } \\
\text { and get off the chest }\end{array}$ & Degree & 2.20 & 0.17 & 1.87 & 0.11 & 3.69 & Indicated \\
\hline$\varepsilon$ & Slow front somersault & Degree & 2.60 & 0.021 & 1.88 & 0.14 & 3.22 & Indicated \\
\hline 0 & $\begin{array}{l}\text { Handstand rolling } \\
\text { forward }\end{array}$ & Degree & 2.50 & 0.58 & 1.91 & 0.011 & 3.74 & Indicated \\
\hline 7 & Total degree & Degree & 12.23 & 0.11 & 9.15 & 0.0032 & 3.44 & Indicated \\
\hline
\end{tabular}

$*$ Value $(\mathrm{T})$ at the level of significance $(0.05)=1.697$

As shown in Table (4), there are statistically significant differences between the two mean measurements of the experimental and control groups in the components of motor compatibility and skill performance and for the benefit of the experimental research group.

\section{Discuss the results}

It is clear from Table (2) that there are statistically significant differences between the mean of pre and post measurements of the experimental group in the variables of the components of motor compatibility and skill performance and in favor of the post measurement, where the value of $(\mathrm{T})$ tabular value is greater than its calculated at the significance level (0.05) and the researcher attributed that improvement To use the sliding disc exercises on the experimental group students.

The researcher believes that the components of kinetic compatibility harmonic capabilities require special development in aesthetic skills complex installation as well as complex skills and repetitive within the total ground movements where these skills need an advanced level of control and control of performance,

And this is what the abilities of the components of 
kinetic compatibility when developing, which This is reflected in the availability of a high rate of control and control during motor performance.

In this regard, Heba Abdel Azim (2005) 16 indicates that the prevalence of the use of non-traditional means is one of the recent trends in the field of sports training, where the use of nontraditional means to increase the effectiveness of the use of the functional potential of the athlete, such as the use of devices and assistive devices To improve the level of physical abilities.

The researcher attributed this improvement to the application of the proposed training program using the slipping disc exercises under consideration, which led to improving the level of skill performance by developing the ability to link the technical skills used in motor performance skills of technical gymnasts experimental group.

The results of this study are consistent with the study of "Maha Alhjersi" "Hala Kassem" (2009) (14), Sameh Magdy (2014) (6) in that the use of sliding disc exercises
Gliding positive effect in improving the level of physical abilities of the players.

The researcher attributed this improvement in the level of components of motor compatibility to the positive impact of the slipping disc exercises, which included a variety of exercises that work to develop physical and motor qualities under consideration as students have been attracted to work through the exercises and the performance of the distinctive motor and performs well and new and works on their enjoyment and suspense

Where they have never been trained with such a method and that tool and also their positive interaction led to the speed of an attractive training climate, which helped to invest time and save a lot of effort during the performance and freedom of movement in all directions and spaces in the place of play and this type is considered One of the innovations of training and its application leads to a big leap in the level of players as well as the effects of players' interest and urging them to compare their performance. 
Some of the sliding disc exercises were comprehensive, balanced and integrated in the development of physical abilities, taking into account individual differences and the principle of gradual increase in load. This is consistent with the findings of both studies.

From "Maha Mohammed Alhjersi, Hala Ahmed Kamel (2009) (6) that the training program, which is comprehensive and balanced in the development of all elements of fitness in addition to taking into account the differences between the individual players positively affect the development of physical abilities, which achieves the first hypothesis of research,

Which It states that there are statistically significant differences between the averages of pre and post measurements in the level of the components of the motor compatibility and the level of skill performance on the ground movements of the students of the experimental research group.

It is clear from Table (3) that there are statistically significant differences between the mean of the pre and post measurements of the control group in the harmonic variables and skill performance and in favor of the post measurement where the value of (T) table is greater than it's calculated at the level of significance (0.05)

This is due to the traditional program applied within the college, which is characterized by different rhythm of effort during performance, which helped to exchange performance between anaerobic and antenna work.

The researcher attributes this result to the fact that the traditional program helped to develop the components of motor compatibility to a limited extent of high-intensity exercises, but not organized in an optimal organization that requires speed in the movements of the legs and strength in the abdominal muscles, as it develops the element of compatibility in addition to the strong performance of the arms,

Which helps to The development of the distinctive force with speed and agility and thus have achieved the second hypothesis, which 


\section{6}

provides that there are statistically significant differences between the averages of pre and post measurements in the level of some components of motor compatibility and the level of skill performance on the ground movements of the students of the research group Armpits.

It is clear from Table (4) that there are statistically significant differences between the two mean measurements of the experimental and control groups in the components of motor compatibility and skill performance and for the benefit of the experimental research group.

The researcher attributes this improvement between the two groups to the proposed program using sliding disc exercises which contributed to improving the components of motor compatibility. Improved skill performance on the ground movements machine.

This improvement is due to the sliding disc training program, which gave the opportunity for students to continue to perform and thus improve the level of skill performance.
He also took into account the researcher in the development of the proposed program to contain a set of exercises that work to develop many elements of fitness that have the same motor path The parts of the skills to be learned which are consequently related to improving the skill performance of the skills in question.

One of the most important characteristics of sliding disc exercises is that they perform more than one member of the body at the same time.

This diversity in sliding disc exercises in terms of the nature of movement and the way of performance and different speed contribute effectively to improve the harmonic capabilities under consideration for the experimental group.

The results of this study are consistent with the mechanism of "Howayda Fathi and Madiha Abdul Qawi" (2008) (17) to the importance of harmonic and kinetic abilities in being composite attributes that do not appear individually and serve to serve this building on the one hand 
and on the other hand training of harmonic and kinetic abilities It works on the development of common abilities in performance and that leads to the development of physical qualities,

Which works on the development of training and educational capabilities, and that when given these exercises in an interesting and varied serve in the installation and construction of the activity practiced, which increases the common physical characteristics with harmonic abilities.

The results of the research are also consistent with the mechanism of "Maurice" (2002) (21) that the development of motor and physical abilities is closely related to the development of motor skills, as students cannot master the motor skills in gymnastics in the absence of special interoperability In this activity,

The higher the level of motor skills and harmony among students the higher the ability to learn new skills, as it affects the mastery of movements previously learned and contributes to their development and high level because high skill level is directly linked to increased performance and improve the harmonic abilities of students, These results are consistent with those of Sameh Magdy (2014), (6), Maha Mohamed El Hagrasy, and Hala Ahmed Kamel (2009) .14 Slip disc training effectively contributes to improved skill performance.

Thus, the third hypothesis of the research has been achieved, which states that there are statistically significant differences between the two dimensions of the two metrological measurements in the experimental and control groups at a level in the components of motor compatibility and skill performance on the ground movements apparatus and in favor of the telemetry in the experimental research group.

\section{Abstracts:}

In the light of the research results, the researcher reached the following conclusions:

1-Slipping disc exercises have a clear positive impact on the level of components of motor compatibility among students 
of the second year in gymnastics.

2-slipping disc exercises have a positive and clear impact on the level of skill performance on the ground movements in gymnastics.

\section{Recommendations:}

In the light of the search results, the researcher recommends the following:

1-Use sliding disc exercises in other sports.

2-Develop similar programs suitable for different ages of males and females.

3-Conducting other similar studies dealing with other variables not addressed in the present study.

\section{References}

1-Abu Ala Abdel-Fattah: Physical training physiological foundations, I 1, Dar al-Fikr alArabi, Cairo, 1997.

2-Ashraf Saber, Iqbal Kamel, Jamal Al-Shafei, Samia AlHijrasi and others: Fourth Grade Teacher's Guide Physical Education, Ministry of Education (Book Sector), M, 2003.

\section{3-Ashraf Mohamed Bassim:}

A proposed program for the development of motor compatibility for swimming dolphin and its impact on the level of skill performance, Ph.D. (unpublished), Faculty of Physical Education for Boys, Helwan University, 2000.

4-Billy Blanks : The Tea-bo Way "California "U.S.A.2000 .

5-Docherty Dmorton : Focns skill Devilment in Teaching Gymnastics

Eandian Association For Helth Phvsical Education and Recreation Journal 48 AR2004 .

\section{6-Essam}

Abdul-Khaliq:

Mathematical training (foundations - theories applications), "I 12, Dar AlMaaref, Cairo, 2003.

\section{7-Gehan Abdel Moneim}

Essawy: The Effect of Using Ball to Develop Neuromuscular Compatibility on the Electro-Muscular Activity of Some Upper Limb Muscles of Rhythmic Gymnastics Junior, PhD Thesis (Unpublished), Faculty of Physical Education for Girls, Helwan University, 1999.

\section{8-Heba Abdel Azim Hassan:}

The effect of an educational program for the balance beam on the harmonic capabilities and skill level performance of students of the Faculty of Physical Education, Ph.D. Thesis, Assiut University, 2005. 
9-Howayda Fathi Sayed and Madiha Mahmoud Abdel Qawy: The Effect of a Proposed Program Using Typo Exercises on Some Harmonic Abilities and Skill Performance Level in Gymnastics and Reducing the Level of Aggressive Behavior of Pupils of the First Cycle of Basic Education, Published Research, Journal of Sports Science and Arts, Volume 30, Part I, Faculty of Physical Education for Girls, Helwan University, 2008.

10-Islam Mosaad: The effect of a qualitative training program for components of neuromuscular harmony on the effectiveness of some of the composite skill performances of football youth, Master Thesis (unpublished), Faculty of Physical Education Mansoura University, 2007.

11- Jensen and Shultz :Applied Kinesiology the Scientific study of Human Performance, 2 nd ed, Inc, 2007

\section{2-Maha Mohamed El-} Hagrasy, Hala Ahmed Kamel: "Effect of ice training on improving some elements of physical fitness of volleyball and karate players (comparative study), published scientific research, Journal of Mathematical

Sciences, Faculty of Physical Education, Minia University, 2009

13-Maurice R.et al : "Validation and calibration of physical Activity monitors in children " The North American Association For the study of obesity Research (150 :157)، 2002 .

\section{4-Mohammed Abdul Ghani}

Othman, "Kinetic Learning and Sports Training", 6th floor, Dar Al-Qalam, Kuwait, 2003.

\section{5-Mohamed}

Shehata weight

"knowledge

Alexandria, 2002

\section{6-Mohamed}

Abdel Salam,
Ibrahim training, facility, Performance and Instructional Steps for Throat and Parallel Horse Exercises, Dar Al Maaref Alexandria, 2003.

\section{7-Mohamed} Sobhy Hassanein, Kamal Abdel Hamid: Physical Fitness and its Components, Dar Al-Fikr Al-Arabi, Cairo, 2001.

18-Mukhtar Salem: "Sports Equipment Technology", AlMa'aref Foundation, Beirut, 2001.

19-Musaad Ali Mahmoud, Mahrous Qandil: Physical 
Education and Sports for Basic Education, National Library, 2005.

20-Sameh Mohamed Magdy, The Effect of Using Slip Disc Exercises on Some Physical and Harmonic Abilities of the National Team of Sword Fencing, Published Scientific Research, Journal of Physical Education Sciences, Faculty of Physical Education, Helwan University, 2014.

21-Te poel ,H.D.S : Tae-Bo atrend sport for school sport tae bo technique and course structure of a cureent fitness program ,lehrhilfen fure den sportenterrichs 51,p 1.52004.
22-Wessam Adel El-Sayed, A Proposed Program for the Development of Neuromuscular Compatibility and its Effect on Performance Level in Kinetic Expression, Master Thesis (Unpublished), Faculty of Physical Education for Girls, Helwan University, 1999.

23-htttp// www.savvier

Fitness.com / gliding- disks.asp 24- http//

www.allbusiness.com / marketing-advertising 25-http// www. Brigh thub.com / health/ fitness/ articales 5 26-htttp// www.gliding disks.com /top fitness proshtml 